\title{
Political budget cycles and election outcomes
}

\author{
Jeroen Klomp • Jakob de Haan
}

Received: 20 February 2011 / Accepted: 12 April 2012 / Published online: 26 April 2012

(C) The Author(s) 2012. This article is published with open access at Springerlink.com

\begin{abstract}
This paper addresses two empirical questions. Is fiscal policy affected by upcoming elections? If so, do election-motivated fiscal policies enhance the probability of re-election of the incumbent? Employing data for 65 democratic countries over 1975-2005 in a semi-pooled panel model, we find that in most countries fiscal policy is hardly affected by elections. The countries for which we find a significant political budget cycle are very diverse. They include 'young' democracies but also 'established' democracies. In countries with a political budget cycle, election-motivated fiscal policies have a significant positive (but fairly small) effect on the electoral support for the political parties in government.
\end{abstract}

Keywords Election outcomes $\cdot$ Political budget cycles $\cdot$ Multilevel model

JEL Classification E62 - H62

\section{Introduction}

This paper addresses two empirical questions. Is fiscal policy affected by upcoming elections? If so, do election-motivated fiscal policies enhance the probability of re-election of the incumbent?

As to the first issue: several recent studies suggest that political budget cycles occur, but there is disagreement about the circumstances making election-motivated budget deficits

J. Klomp

Wageningen University, Wageningen, The Netherlands

J. de Haan

University of Groningen, Groningen, The Netherlands

J. de Haan ( $\square)$

De Nederlandsche Bank, PO Box 98, 1000 AB Amsterdam, The Netherlands

e-mail: j.de.haan@dnb.nl

J. de Haan

CESifo, Munich, Germany 
more likely. For instance, opinions differ as to whether political budget cycles are more likely in 'young' democracies compared to 'established' democracies (Persson and Tabellini 2002; Shi and Svensson 2006; Brender and Drazen 2005).

It is quite surprising that the second issue has hardly been researched. Brender and Drazen (2008) do not find evidence that election-motivated budget deficits enhance the chances of re-election of the incumbent. In fact, they even report that these deficits reduce the probability that an incumbent is re-elected as voters punish politicians who create deficits. ${ }^{1}$

Our analysis is based on data for 65 democratic countries over the period 1975 to 2005. To estimate the impact of election-induced fiscal policy on the incumbent's support we use a two-step approach. In the first step, we estimate whether elections affect the government's budget balance and government spending. Most recent studies on election-motivated fiscal policy at the national level use panel models for a large sample of countries, pooling the data. However, in view of the heterogeneity of the countries included in those studies, it is questionable whether the data can be pooled (Pesaran et al. 1996). According to Pesaran et al. (1999), neglecting parameter heterogeneity in a pooled panel estimation procedure can produce inconsistent and misleading estimates of the long-run coefficients. Tests of heterogeneity indicate that our data cannot be pooled. We therefore use a semi-pooled model suggested by Hsiao et al. (1999). In this model, the political budget cycle (PBC) effect varies across countries, while the other control variables are restricted to be homogenous. Employing an election variable that takes the timing of the election in the course of the year into account as suggested by Franzese (2000), we find that fiscal policy in most-but not all-countries in our sample is hardly affected by upcoming elections. The countries for which we find a significant political budget cycle are very diverse. They include 'young' democracies but also 'established' democracies.

In the second step of our analysis, we examine for countries with election-motivated fiscal policy, whether this PBC increases electoral support for the incumbent. In contrast to Brender and Drazen (2008), we take into account that many countries have coalition governments (Hanusch 2012). We therefore focus on votes received by political parties participating in the government. We conclude that government spending has a significant positive (but fairly small) effect on the electoral support for the parties in government. We also find an indirect positive effect of election-motivated fiscal policy through its impact on economic growth.

The remainder of the paper is structured as follows. The next section discusses in more detail how our contribution is related to previous studies of political budget cycles and economic voting. Section 3 shows our results for the influence of elections on fiscal policy, while Sect. 4 presents our estimates of the relationship between political budget cycles and election outcomes. The final section offers our conclusions.

\section{Previous studies}

We combine two strands of the political economy literature. The first one addresses the existence of a political budget cycle. Older theoretical PBC models emphasize the incumbent's intention to secure re-election by maximizing his/her expected vote share at the next election (Nordhaus 1975). It is assumed that the electorate is backward looking and evaluates the government on the basis of its past track record. As a result, these models imply that governments, regardless of ideological orientation, adopt expansionary fiscal policies in

\footnotetext{
${ }^{1}$ In Sect. 2, we will also discuss some recent studies on the effect of fiscal policy on local election outcomes.
} 
the late year(s) of their terms in office in order to stimulate the economy (Potrafke 2012). More recent $\mathrm{PBC}$ models emphasize the role of temporary information asymmetries regarding the politicians' competence level in explaining electoral cycles in fiscal policy. In these models, signalling is the driving force behind the PBC (see, e.g., Rogoff and Sibert 1988; Persson and Tabellini 2002; and Shi and Svensson 2006). For instance, in the moral hazard model of political competition of Shi and Svensson (2006), politicians may behave opportunistically even if most voters know the government's policy, but some voters are uninformed. The larger is the number of voters that fail (ex ante) to distinguish electionmotivated fiscal policy manipulations from incumbent competence, the more the incumbent profits from boosting expenditures before an election. Alt and Lassen (2006) argue that the greater is the transparency of the political process, the lower is the probability that politicians behave opportunistically. Drazen and Eslava $(2006,2010)$ explain the relationship between opportunistic spending of the government and the election outcome within a game theoretic framework. The incumbent uses public expenditure to attract votes. In equilibrium, expenditures targeted to particular voters are higher in an election period than in a non-election period. Swing voters will rationally vote for the incumbent who provides more targeted expenditures even though they know that such expenditures may be electorally motivated.

Brender and Drazen (2005) argue that until recently a PBC was generally thought to be a phenomenon of less developed economies. For instance, Schuknecht (1996) reports evidence for a PBC in his sample of 35 developing countries over the period 1975-1992. Likewise, Block (2002) finds for a cross-section of 44 Sub-Saharan African countries that the government's budget deficit increases by 1.2 percentage points in election years. ${ }^{2}$ However, several recent studies present evidence for the existence of a PBC in a large crosssection of both advanced and developing countries. For instance, Shi and Svensson (2006) report significant pre-electoral increases in the government budget deficit for their panel of 85 developing and advanced countries over the period 1975-1995. Moreover, Persson and Tabellini (2002) find statistically significant tax decreases before elections in their sample of 60 democracies over the period 1960-1998. According to Brender and Drazen (2005), the results of the studies of Shi and Svensson (2006) and Persson and Tabellini (2002) are driven by the experiences of so-called 'new democracies', where fiscal manipulation may be effective because of the lack of familiarity with electoral politics in these countries. They argue that once the 'new democracies' are removed from the sample, evidence in support of the PBC disappears.

However, several recent studies also focusing on 'established democracies' report evidence on the existence of a PBC. For instance, Grier (2008) reports that the timing of elections exerts a significant influence on quarterly real GDP growth in the US, while Tujula and Wolswijk (2007) find support for a PBC in their sample of OECD countries for the period 1975-2002. Mink and De Haan (2006) provide similar evidence for European Union (EU) member states after the start of the monetary union. ${ }^{3}$ Similarly, Efthyvoulou (2011) reports for the $27 \mathrm{EU}$ member states over the period 1997-2008 that incumbent governments tend to

\footnotetext{
${ }^{2}$ Similarly, Schuknecht (2000) finds for a sample of twenty-four developing countries over 1973-1992 that incumbent governments tend to increase public investment prior to elections. Vergne (2009), using data on 24 developing countries from 1975 to 2001, reports that elections shift the composition of spending towards current expenditures and away from capital expenditures.

${ }^{3}$ Also several studies of local elections report evidence of a PBC. A recent example is the study of Aidt et al. (2011), who also provide references to previous studies. Aidt et al. use data from 278 Portuguese municipalities from 1979 to 2005 and find that the cycle is largest when the need for the incumbent to signal competency is at its peak.
} 
manipulate fiscal policy in order to maximize their chances of being re-elected. He finds that the relative importance of non-economic issues prior to elections and the uncertainty over the electoral outcome can to a large extent explain the variability in the sizes of PBCs across and within the EU countries. Katsimi and Sarantides (2012) examine the impact of elections on different types of fiscal expenditure and revenue for a sample of 19 'old' democracies over the period 1972-1999. They report that elections shift the composition of public expenditures towards current expenditures and away from capital expenditures. However, they do not find evidence of an electoral cycle for government deficits and expenditures, but do find a negative effect of elections on revenues.

In view of the heterogeneity of our sample, we allow the impact of elections to vary across countries. ${ }^{4}$ Our results suggest that fiscal policy in most—but not all—countries in our sample is hardly affected by upcoming elections. The countries for which we find a significant political budget cycle are very diverse. Some of them are developing countries, while others are OECD countries. They include 'young' democracies but also 'old' democracies.

The second strand of literature on which the current paper is based focuses on the economic determinants of election outcomes. Following studies such as those of Kramer (1971), Tufte (1978) and Hibbs (1987)—who all find that outcomes of U.S. presidential elections are influenced by the performance of the U.S. economy-many subsequent studies have examined the impact of the state of the economy on voting behavior. There is substantial evidence that the state of the economy affects voting behavior. Lewis-Beck (1988) finds this, for instance, for Germany, France, Italy, Spain, and the United Kingdom. Indeed, in their review of the economic voting literature Lewis-Beck and Stegmaier (2000: 211) conclude that "Economics and elections form a tight weave.... For all democratic nations that have received a reasonable amount of study, plausible economic indicators, objective or subjective, can be shown to account for much of the variance in government support."

Brender and Drazen (2008) provide three reasons why expansionary fiscal policies in a pre-election year may lead to a higher re-election probability. First, a fiscal expansion could stimulate economic growth. Voters may interpret more vigorous economic growth as a signal of a talented incumbent, thereby making reelection more likely. Second, government expenditures for special target groups may increase the number of votes given by this group to the incumbent. Finally, voters may simply prefer low taxes and high spending and reward politicians who deliver these.

A few recent studies use local election data to examine whether fiscal policy affects the incumbent's re-election chances. These studies report mixed results. Brender (2003) does not find robust results using data for Israel, while Aidt et al. (2011) conclude that expansionary fiscal policy increases the win margin of Portuguese mayors. Using data for Colombian municipalities, Drazen and Eslava (2010) provide evidence that a pre-electoral increase in targeted expenditures combined with a contraction of other types of expenditure affect voter behavior.

Brender and Drazen (2008) is the only study of which we are aware that refers to the effect of election-induced fiscal policy at the national level. Employing data for a sample of 74 countries over the period 1960-2003, these authors do not find evidence that electionmotivated budget deficits enhance the chances of re-election of the incumbent. In fact, they even report that these deficits reduce the incumbent's chances of reelection as voters punish politicians who create deficits. Our study differs from Brender and Drazen's work, as we do

\footnotetext{
${ }^{4}$ Similarly, Bayar and Smeets (2009) use a dynamic random coefficient model to explain the relation between government deficits and elections in EU countries. In line with the results of Mink and De Haan (2006), they find evidence for opportunistic behavior of policymakers in the majority of the EU countries.
} 
not analyze whether the Chief Executive benefits from election-motivated fiscal policies. As Hanusch (2012) points out, certainly in the OECD but also in other parts of the world, the government is formed by a coalition of parties. Although it seems safe to assume that each coalition member seeks re-election, some parties may gain more from budget manipulation than others. That is why we focus on the electoral support that the political parties in government receive. We also take the potential indirect effect of election-induced expansionary fiscal policies on economic growth into account as economic growth has been found to be an important determinant of election outcomes in the voting literature.

\section{Political budget cycles}

\subsection{Data and method}

We use a large unbalanced cross-country time-series dataset for 65 advanced and developing countries over the period 1975 to 2005 . We consider only country-years with a minimum level of democracy as the theory of the PBC presumes that competitive elections take place. We therefore enter only country-years with a Polity IV democracy score of at least six. ${ }^{5}$ Appendix 1 lists all countries and years in our dataset. The fiscal data are taken from the International Financial Statistics and the Government Finance Statistics of the IMF, while the election data come from electionsource.org and various issues of the Political Handbook of the World. Appendix 2 provides a detailed description of all data used and their sources. The model can be specified as ${ }^{6}$ :

$$
f_{i t}=\left(\alpha+\eta_{i}\right)+\beta f_{i t-1}+\gamma X_{j i t-1}+\lambda E L E C_{i t} \times \eta_{i}+\varepsilon_{i t} .
$$

The variable $f_{i t}$ is a fiscal indicator (budget balance or total spending) in country $i$ in year $t, X_{j i t-1}$ is a vector of (lagged) control variables with $j$ elements, $E L E C_{i t}$ is an election variable, $\eta_{i}$ is a country fixed effect, and $\varepsilon_{i t}$ is an error term. Several election studies, such as Persson and Tabellini (2002), Brender and Drazen (2005) and Shi and Svensson (2006), use pooled time-series to identify the presence of a political budget cycle. However, it is questionable whether a pooled estimator is the appropriate estimation technique in view of the possible heterogeneity in our large sample. To examine this issue in more detail, we perform a modified Chow test on the election coefficient suggested by Baltagi (1995). This test compares the model under the restriction of common slopes across countries with the model that allows for heterogeneous slopes. The test statistic indicates that the null hypothesis that the data can be pooled is rejected at conventional significance levels (the p-value of the test is 0.03 ).

We therefore estimate a semi-pooled model in which all control variables have a homogenous impact, while the effect of the PBC variable is allowed to vary across countries. ${ }^{7}$ Following Franzese (2000), our election variable takes the timing of an election in the course

\footnotetext{
${ }^{5}$ According to the definition of Polity IV, countries with a score higher than six are regarded as democratic (Jaggers et al. 2006). However, we have also adopted cut-off points of the Polity IV score of two, four and seven. This yields very similar results (available on request).

${ }^{6}$ We also test the model with time dummies, but they turn out to be insignificant as do the interaction terms between the time dummies and the election variable.

${ }^{7}$ We have also estimated individual regressions for each country. The results remain in line with our main results throughout the paper. However, this reduces the degrees of freedom per country dramatically and therefore evaluating the consistencies of the coefficients is not warranted.
} 
of the year into account. It is calculated as $M / 12$ in an election year and $(12-M) / 12$ in a pre-election year, where $M$ is the month of the election. In all other years its value is set to zero.

We consider elections only if the government has sufficient opportunity to change its fiscal policies. It usually takes some time before the impact of election-motivated fiscal policies becomes visible. When there are, for instance, elections shortly after the fall of a cabinet, the government may have little chance for pursuing expansionary fiscal policy. As a cut-off point, we use one year. So, an election is included if it is held on the fixed date (year) specified by the constitution, or if the election occurs in the last year of a constitutionally fixed term for the legislature. Also when an election is announced more than one year in advance, it is taken up in the analysis. ${ }^{8}$

The vector $X_{j i t-1}$ contains control variables suggested by previous studies. The controls are entered with a one-year lag. We include real GDP per capita to control for the level of development of a country as this could influence voters' preferences for public goods as well as the size of the tax base. The growth rate of real GDP captures the influence of the business cycle. Sometimes globalization is argued to restrain governments' fiscal policies. We use the KOF globalization index (Dreher 2006; Dreher et al. 2008) to control for this. Also demographic factors may affect fiscal policies. We therefore include the so-called dependency ratio, which measures the ratio of the elderly to people of working age. A larger share of the elderly will lead to increases in government spending due to, for example, greater social security and health care spending. Inflation may affect government receipts and expenditures through nominal progression in tax rates and tax brackets, and via priceindexation of receipts and expenditures. On the other hand, unexpected inflation erodes the real value of nominal government debt so that the overall effect of inflation on the budget balance is not clear a priori (Mink and De Haan 2006). Higher unemployment will increase government spending on social security and decrease revenues, and hence raise the budget deficit. Finally, we include a dummy variable that is one when a country is a member of a monetary union at time $t$. Most monetary unions impose constraints on the public budget's balance, like the Stability and Growth Pact within the European Economic and Monetary Union (EMU). ${ }^{9}$

We also include several political control variables suggested by previous studies. Persson and Tabellini (2002) argue that elections may have a different effect on fiscal policy under proportional and majoritarian electoral rules. Proportional elections induce politicians to seek support from larger groups in the electorate. It is then plausible to expect budget deficits to be larger under proportional electoral rules than under majoritarian electoral rules. Likewise, there may be differences between parliamentary versus presidential systems. In contrast to a parliamentary system, in a presidential system the executive cannot be brought down by the legislature, but he or she is directly accountable to the voters and this

\footnotetext{
${ }^{8}$ However, as governments were perhaps already using expansionary fiscal policy before announcing the election date, we have also estimated all regressions reported in this paper including all elections. Our main findings are very similar to those presented in the paper. The results are available on request.

${ }^{9}$ We have experimented with three alternatives. The first dummy takes the value one in EMU countries between 1992 and 1998. The second dummy takes the value one in EMU countries after 1998 and the final dummy also takes the value one in monetary unions other than the EMU. The results of the models using the first two dummies instead of the third one are very similar to those reported.
} 
may affect fiscal policy. We therefore include dummy variables that are 1 for majoritarian systems and parliamentary systems, respectively. ${ }^{10}$

Furthermore, coalition governments arguably have different fiscal policies than singleparty governments. Due to the common pool problem, government expenditures and budget deficits are expected to be larger the more parties take part in government.

We also include a partisan variable to control for differences between right and left wing governments in fiscal policy. According to the partisan approach, politicians focus on the interests of their respective constituencies. There is evidence suggesting that spending priories differ among right and left wing governments, but whether partisan factors influence budget deficits is less clear (cf. Hallerberg and Clark 2000). Our partisan variable is measured on a scale running from -1 (full left wing) to +1 (full right wing). The variable is based on the data provided by the Database on Political Institutions of the World Bank. All explanatory variables are lagged to avoid simultaneity and endogeneity problems. The lag structure is determined by Akaike's Information Criterion.

\subsection{Empirical results}

Table 1 presents the estimation results of Eq. (1). To obtain robust and consistent standard errors we use the bootstrap method with 1,000 replications. ${ }^{11}$

We find a significant effect of the dependency ratio on fiscal policy. A larger population share of the elderly raises government spending and lowers government revenues and therefore the budget deficit rises. Also the unemployment rate and economic growth affect fiscal policy outcomes, but income per capita and inflation turn out to be insignificant. Our results suggest that left-wing governments have larger budget deficits than right-wing governments. Left-wing governments spend more than right-wing governments, but do not raise taxes accordingly. The coefficient of the KOF globalization indicator is not significantly different from zero. Our results also suggest that governments in a majoritarian electoral system spend more than governments in a proportional electoral system and that membership in a monetary union reduces the budget deficit.

Most importantly, we find that on average elections hardly affect fiscal policy. The election variable is significant only at the $10 \%$ level in the model for government spending, but not in the model for the government budget balance. However, we do find significant political budget cycle effects in some countries, which are identified in Appendix 1. The PBC effect for each country is determined by estimating the cross-partial derivative and the corresponding t-value. The countries for which we find a significant political budget cycle are very diverse. Some of them are developing countries, while others are OECD countries. They include 'young' democracies but also 'old' democracies. The latter finding does not lend support to the view that PBCs occur only in countries that have little experience with democratic elections. In Sect. 4.3 we will examine this argument of Brender and Drazen (2005) in more detail.

In 23 countries we find a significant effect of elections on the budget balance. As the detailed results in Appendix 1 show, the significant effect varies between $-2.56 \%$ for Turkey to $-0.13 \%$ for Italy. For government spending we find for 24 countries a significant election effect; the estimated coefficient varies between 2.45 for Japan to 0.19 for Norway.

\footnotetext{
${ }^{10}$ We examine whether a president has legislative powers in the realm of fiscal policy. If not, and if the government is accountable to parliament through a confidence requirement, the country is classified as a parliamentary regime.

${ }^{11}$ We clustered the standard errors using the Huber-White procedure.
} 
Table 1 Semi-pooled model—estimation results for Eq. (1)

Dependent variable

Budget balance

Total spending

(1)

(2)

\begin{tabular}{|c|c|c|}
\hline \multirow[t]{2}{*}{ Lagged dependent variable } & $0.375^{* *}$ & $0.769^{* *}$ \\
\hline & {$[2.86]$} & {$[2.63]$} \\
\hline \multirow[t]{2}{*}{ Partisan variable } & $0.408^{* *}$ & $-0.553^{*}$ \\
\hline & {$[2.80]$} & {$[-1.74]$} \\
\hline \multirow[t]{2}{*}{ Parliamentary electoral system } & -1.429 & 1.871 \\
\hline & {$[-1.31]$} & [1.42] \\
\hline \multirow[t]{2}{*}{ Majoritarian electoral system } & $-2.032^{* *}$ & $1.986^{* *}$ \\
\hline & {$[-2.06]$} & {$[2.00]$} \\
\hline \multirow[t]{2}{*}{ Number of coalition parties } & -0.509 & 0.467 \\
\hline & {$[-0.35]$} & {$[0.31]$} \\
\hline \multirow[t]{2}{*}{ Globalization } & -0.347 & 0.838 \\
\hline & {$[-1.26]$} & {$[0.90]$} \\
\hline \multirow[t]{2}{*}{ Age dependency ratio } & $-0.989^{* *}$ & $0.329^{* *}$ \\
\hline & {$[-2.95]$} & {$[2.26]$} \\
\hline \multirow[t]{2}{*}{ Unemployment rate } & $-0.591^{* *}$ & $0.180^{*}$ \\
\hline & {$[-2.25]$} & {$[1.80]$} \\
\hline \multirow[t]{2}{*}{ Economic growth } & $0.029^{* *}$ & -0.027 \\
\hline & {$[3.03]$} & {$[-2.77]$} \\
\hline \multirow[t]{2}{*}{ Income per capita } & $0.529^{*}$ & -0.440 \\
\hline & {$[1.66]$} & {$[-1.07]$} \\
\hline \multirow[t]{2}{*}{ Inflation rate } & -0.151 & -0.110 \\
\hline & {$[-1.06]$} & {$[-0.94]$} \\
\hline \multirow[t]{2}{*}{ Monetary union } & $0.101^{* *}$ & -0.089 \\
\hline & {$[2.01]$} & {$[1.43]$} \\
\hline \multirow[t]{2}{*}{ Election } & -0.888 & $0.311^{*}$ \\
\hline & {$[-1.47]$} & {$[1.79]$} \\
\hline Number of observations & 1493 & 1493 \\
\hline Number of countries & 65 & 65 \\
\hline Log likelihood test (p-value) & 0.000 & 0.000 \\
\hline
\end{tabular}

Note: t-values are shown in parentheses. ${ }^{*}{ }^{* *}$ indicates significance at $10 / 5$ percent, respectively

\section{Effect of political budget cycles on election outcomes}

\subsection{Method}

Next, we estimate the effect (if any) of election-motivated fiscal policy on election outcomes. Most election studies focus on the re-election of (the party of) the chief executive (see, for example, Brender and Drazen 2005 and Dreher 2004). This makes sense in a one-partygovernment system, but less so in a multi-party coalition system. In such a system, one party in government may lose support from the electorate, while other coalition parties may gain votes. 
We therefore focus on the effect of fiscal policy on the votes received by individual parties in (coalition) governments. We formulate a multilevel (i.e., party $b$ and coalition $q)^{12}$ model given by:

$$
\Delta v_{b q e}=\alpha_{b q}+\beta_{q} \Delta y_{q e}^{E}+\theta_{b q} X_{j b q e}+\gamma_{q} P B C_{q e}+u_{b e}^{v}+u_{q e}^{v},
$$

where $\Delta v_{b q e}$ is the change in the percentage of votes to party $b$ that is in government coalition $q$ in election $e,{ }^{13} \Delta y_{q e}^{E}$ is the economic growth rate in an election year that we include to examine a possible indirect effect of election-motivated expansionary fiscal policy on $\Delta v_{b q e}$. The parameters $u_{b e}^{v}$, and $u_{q e}^{v}$ are the error terms on party and coalition level, respectively. The election year economic growth rate is computed as follows:

$$
\Delta y_{q e}^{E}=\frac{M \times \Delta y_{q t}+(12-M) \times \Delta y_{q t-1}}{12},
$$

where $M$ is the election month and $\Delta y_{q t}$ is the economic growth rate in period $t .{ }^{14}$

The variable $X_{j b q e}$ is a vector of control variables with $j$ elements. The variables in $X_{j b q e}$ are defined as averages during the incumbent government's term in office. This vector contains variables suggested by the literature on economic voting, political controls, and controls referring to the incumbent government and individual political parties.

In the first place, the findings of Kramer (1971), Tufte (1978), Hibbs (1987), Lewis-Beck (1988), Nannestad and Paldam (1994) suggest not only that stronger economic growth, but also that lower inflation and less unemployment may have a positive effect on the re-election of the incumbent. Likewise, Hobolt and Klemmensen (2006) argue that the level of welfare spending also increases the number of votes received by the incumbent party. ${ }^{15}$ Since income inequality may affect the number of votes received by the incumbent, we also take it up as a control variable.

In the second place, we control for some political variables. First, we include a measure of political protest, calculated as the first principal component of government crises, cabinet changes, anti-governmental demonstrations, and strikes (taken from Databanks International 2005). A high level of protest activity indicates that the government is not popular among voters.

Second, we add a proxy for political polarization in a country. It is measured by the difference between the ideology of the incumbent government and the ideology of the two largest opposition parties. In a highly polarized environment the probability of policy disagreements is relatively high, which, in turn may lead to a less effective government and therefore less support from the electorate for the parties in government.

Third, we include two indicators of the political system (majoritarian versus proportional systems and parliamentary versus presidential systems).

Finally, an increase in the number of parties participating in the election may affect the number of votes received by the (parties of the) incumbent government due to a competition effect. We therefore control for this. Likewise, we also control for voter turnout.

\footnotetext{
${ }^{12}$ Following Roubini and Sachs (1989), a presidential system is treated in the same way as a one-party government.

${ }^{13}$ Using the change in the number of seats in parliament yields the same conclusion. The correlation between votes received and seats received is about 0.9 .

${ }^{14}$ As a robustness test, we have also used a pre-election economic growth period of six months. The results remain in line with the results reported in the main text and are available upon request.

${ }^{15} \mathrm{We}$ leave out total government spending because of multicollinearity with welfare spending.
} 
In the third place, we include several variables that represent some characteristics of the incumbent coalition. First, we include a dummy variable that is one if the chief executive is in his last term, thereby controlling for a 'personality effect' according to which voters cast their vote primarily on the basis of the popularity of the chief executive. Second, we take up a variable reflecting the coalition's ideological position to control for partisan effects. Third, we include the Herfindahl-Hirschman index based on the number of seats of the governing parties in parliament as an indicator of the division of power within the coalition. The larger is the index, the more powerful one coalition party is and therefore the more likely that government policies will be attributed to this party. Fourth, we add a dummy variable that reflects that a government is a minority government. Fifth, we include the number of coalition parties. Sixth, we consider the number of years a party has been in government. This variable is included, since after a number of years in power voters often demand change. So the number of years in government will have a negative effect on votes received in the next election. Finally, we take up a dummy that is one in case a political party is the largest coalition party and zero for the other parties in the coalition.

In the fourth place, we take individual government party characteristics into account by adding two party ideology dummies. The first dummy is one if a government party is nationalistic, and zero otherwise. The second dummy is one if a political party is a special interest party based on region or political issues, and zero otherwise. These variables are taken from the updated figures from Beck et al. (2001). ${ }^{16}$

Finally, we include a measure reflecting the political budget cycle $(P B C)$. We use two different PBC indicators. First, we re-estimate Eq. (1), dropping the election variable. The error term captures the unexplained part of the fiscal variable concerned along with the election effect. As our first PBC indicator, we use the difference between the error term in an election year and the average error term during the term in office of the government $(P B C 1)$. To calculate our second PBC indicator, we use the election coefficient $\lambda$ in regression (1). Based on the statistical significance of $\lambda$ we construct a dummy variable taking the value one when $\lambda$ is significant at a $10 \%$ significance level and zero otherwise. ${ }^{17}$ So, PBC2 is computed as follows:

$$
P B C 2_{q e}= \begin{cases}1 & \text { if }\left(P_{\lambda} \leq 0.10\right) \\ 0 & \text { if }\left(P_{\lambda}>0.10\right)\end{cases}
$$

We also take into account that election-motivated expansionary fiscal policies may increase economic growth right before the elections, which, in turn, may increase the number of votes received by the government parties. We estimate the following equation:

$$
\Delta y_{q e}^{E}=\varphi_{q}+\phi_{j} Z_{j q e}+\chi_{q} P B C_{q e}+\mu_{t}^{y}+\eta_{i}^{y}+u_{q t}^{y},
$$

where $\Delta y_{q t}^{E}$ represents economic growth per capita according to Eq. (3) in an election year $E$ and $Z_{j q e}$ is a vector with explanatory variables used by Mankiw et al. (1992), which includes initial real GDP per capita, investment, secondary school enrollment, and the growth of the population. The control variables are defined as averages during the incumbent government's term in office excluding the election year. The variables $\mu_{t}^{y}$ and $\eta_{i}^{y}$ measure the fixed time

\footnotetext{
${ }^{16}$ We also tested a government party ideology variable. However, the correlation between the coalition ideology and government party ideology exceeds 0.8 . We therefore include only the ideology of the coalition. The correlation matrix is shown in Appendix 3.

${ }^{17}$ Our qualitative results do not change when we use $5 \%$ significance level as cut-off point (results are available on request).
} 
and country effects, respectively, while $u_{q t}^{y}$ is an error term. Eqs. (2) and (5) are estimated with a multilevel simultaneous equation model. ${ }^{18}$

\subsection{Results}

Table 2 reports our estimation results for Eqs. (2) and (5). Due to data limitations, the number of countries drops to 59. Column (1) shows our baseline model for the electoral support received by the parties in government that is derived using the general-to-specific approach. That is, we start by estimating a model including all explanatory variables outlined in Sect. 4.1. Next, we drop the least significant variable from the regression specification and estimate the model again. We repeat this procedure until only variables that are significant at the $10 \%$ level remain (see Hendry 1993). An increase in the share of votes to the incumbent party indicates a vote loss of other political parties participating in the election. Therefore we cluster the standard errors at the election level.

The results for the intra-class correlation, which measures the distribution of the total variance, shows that about half of the total variance is due to the variance at the coalition level. This indicates that a multilevel model is appropriate.

We find a significantly negative effect of the number of parties participating in the election. Also political protest has a negative effect on the electoral support for the parties in government. Furthermore, fractionalization reduces the share of the votes received by the parties in government. Also the coefficients of the variable reflecting the number of years that a party has been in government and of the dummy for the largest coalition party are negative.

Our results for the economic variables are in line with the conclusions of Kramer (1971), Tufte (1978), Hibbs (1987), Lewis-Beck (1988) and Nannestad and Paldam (1994) as inflation and economic growth ${ }^{19}$ are important determinants of the popularity of the incumbent. Also spending on welfare has a positive effect on the votes received by the government parties.

Our model for economic growth confirms the findings of Mankiw et al. (1992) that initial GDP (measured by the 10-year lagged GDP per capita) and (human and physical) capital are significantly related to real GDP growth per capita.

In columns (2) and (3) of Table 2 we add our PBC indicators based on the impact of elections on the budget balance. As shown in column (2) of Table 2, election-induced increases in the budget deficit as measured by $P B C 1$ raise the electoral support for the incumbent government parties. We find that a one-point increase in $P B C 1$ increases the vote share of the parties in government by $0.41 \%(p=0.06)$. As shown in column (3), $P B C 2$ also is significant indicating that an increase in the budget deficit for electoral reasons increases the number of votes for the incumbent political parties in the next election. The estimates suggest that a political cycle in the government deficit increases the vote share of the parties in government by $1.1 \%(p=0.06)$. So although the $P B C 2$ measure is significant, the size of the effect is quite small. In contrast to the direct impact, there is no indirect impact of election-induced budget deficits as the $P B C 1$ and $P B C 2$ variables are not significant in the growth regression.

\footnotetext{
${ }^{18}$ We do not present the reduced form of the vote equation in which we substitute the pre-election growth regression into the vote regression, because we are interested in the separate effect of PBCs on voting and economic growth. However, we have also estimated the reduced form and the results are in line with the main model.

${ }^{19}$ We exclude economic growth during the election year because this variable is taken up in the regression separately.
} 


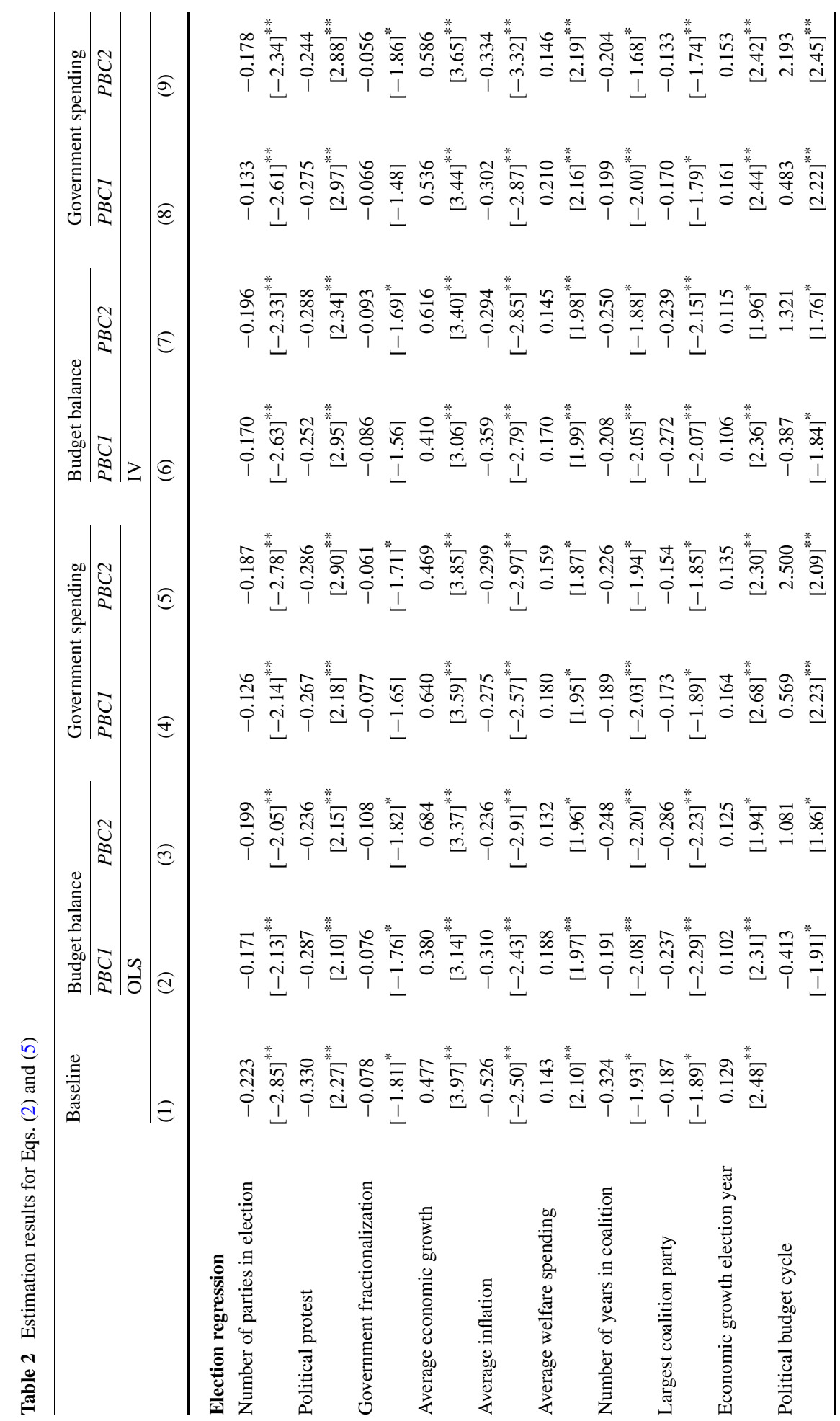




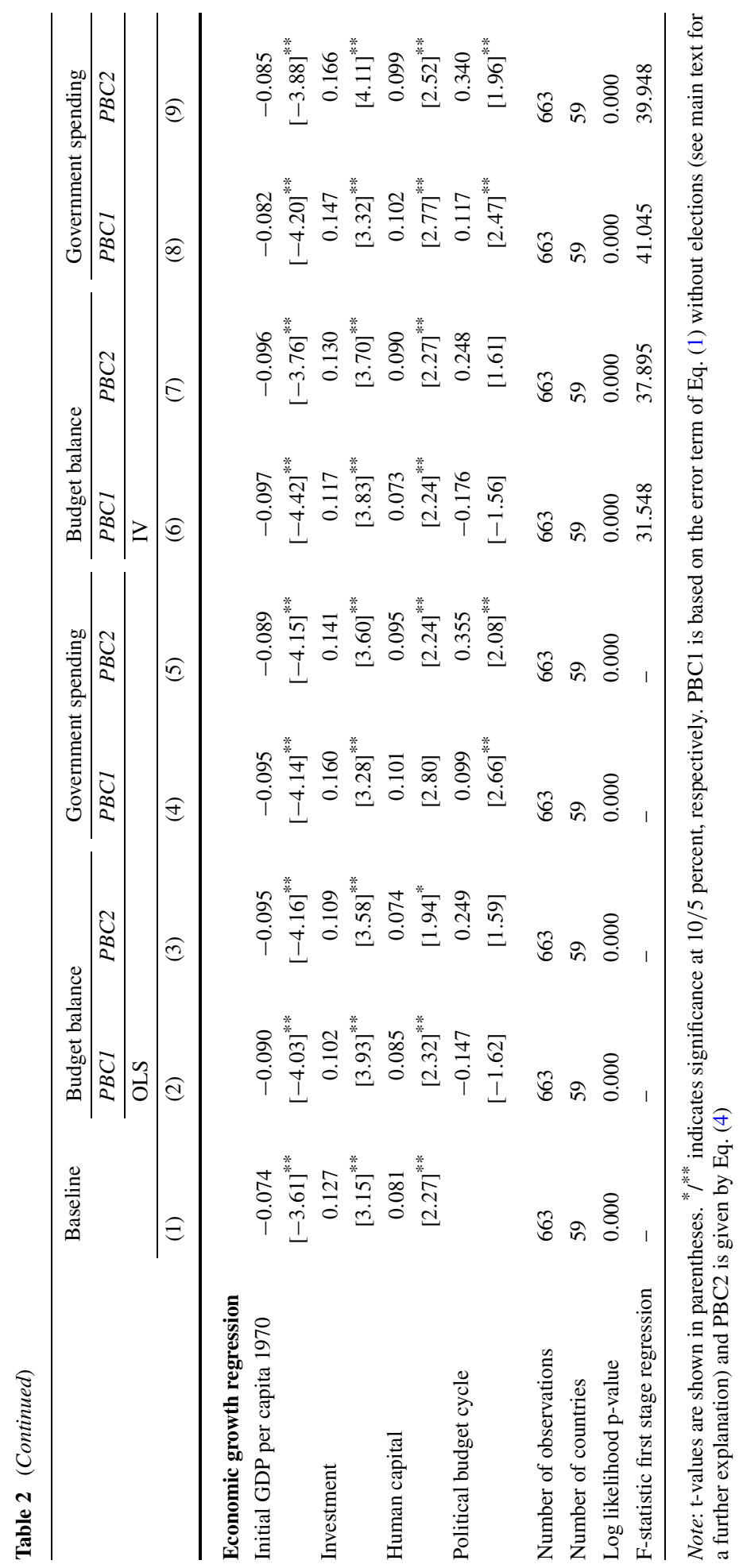


Next we add our PBC variables that are based on the impact of elections on government spending. Both $P B C 1$ (column 4) and $P B C 2$ (column 5) are significant. A one-point increase in $P B C 1$ increases the voting share of the parties in government by $0.57 \%(p=0.02)$. So although the marginal effect of the $P B C 1$ measure is significant, the size of the effect is again quite small. According to the coefficient of $P B C 2$, election-induced increases in government spending increase the voting share by $2.5 \%(p=0.04)$. Furthermore, we find a significantly positive indirect effect of expansionary fiscal policy on the election outcome through higher economic growth in an election year. However, this effect also is rather small. The incumbent government parties increase their share of votes by only $0.03 \%$ through the pre-election economic growth channel.

In conclusion, even though we find evidence that election motivated fiscal policies increase the electoral support for the political parties in the government, the increase in electoral support is rather minor. This can be illustrated by calculating the effect of electionmotivated fiscal policy on the votes received by the parties in government for the five countries with the strongest PBCs. These countries are Turkey, Zambia, Japan, Nicaragua and Malaysia for the PBC in the budget balance and Japan, Malaysia, Turkey, Romania and Colombia for the PBC in government spending. Our estimates suggest that in these countries election-motivated increases in the budget deficit increase the share of the votes of the parties in government by about $0.76 \%$, while election-induced increases in government spending increases the share of votes by about $5.07 \%$.

However, pre-election growth and the election outcome on the one hand and the existence of a PBC on the other may be determined by similar factors. For instance, institutional factors are important determinants of economic growth and some of these (such as the presence of checks and balances) may also affect the existence of political budget cycles. When we fail to control explicitly for these factors, our results might be biased. We therefore use instrumental variables. Brender and Drazen (2005) argue that the existence of a PBC is primarily a phenomenon in new democracies and we therefore use the number of years that a country has been a democracy since 1945 according to Polity IV as an instrument. In addition, we use the level of democracy, also taken from Polity IV, and the lagged dependent variable as instruments.

We check the validity of our instrumental variables used by the Sargan test under the null hypothesis that our set of instruments is valid, i.e., they are uncorrelated with the error term in the structural equation. The results indicate that we cannot reject the null hypothesis indicating that our set of instruments is valid $(p>0.05)$. Next, we apply the Wald test of exogeneity under the null hypothesis that the instrumented variable is exogenous $(p<0.05)$. The results confirm that our set of instruments is valid. The results of the IV regression, presented in columns (6)-(9), are similar to the OLS results presented in columns (2)-(5) of Table $2 .^{20}$

\subsection{Robustness checks}

It is possible that outliers affect the estimation results. Therefore, we re-estimate the regressions in columns (3) and (5) of Table 2 excluding country-years where the dependent or the PBC variable are classified as outlier to test for the sensitivity of our findings for the

\footnotetext{
${ }^{20}$ As suggested by the referee, we have also included the instruments as covariates in the model. The results (available on request) are in line with the results reported in the paper.
} 
Table 3 Sensitivity analysis using $P B C 2$

\begin{tabular}{|c|c|c|c|c|c|c|}
\hline & \multicolumn{3}{|c|}{ Vote regression } & \multicolumn{3}{|c|}{ Growth regression } \\
\hline & Coefficient & t-ratio & p-value & Coefficient & t-ratio & $\overline{\mathrm{p} \text {-value }}$ \\
\hline \multicolumn{7}{|l|}{ (1) Outlier correction } \\
\hline Budget balance cycle & 1.650 & 1.721 & 0.086 & -0.260 & 1.450 & 0.147 \\
\hline Spending cycle & 2.734 & 2.536 & 0.011 & 0.334 & 2.145 & 0.032 \\
\hline \multicolumn{7}{|c|}{ (2) Learning effect sample } \\
\hline Budget balance cycle & 1.200 & 1.566 & 0.118 & 0.217 & 1.571 & 0.116 \\
\hline Spending cycle & 1.957 & 1.922 & 0.055 & 0.275 & 1.752 & 0.080 \\
\hline \multicolumn{7}{|c|}{ (3) Low governance countries } \\
\hline Budget balance cycle & 1.775 & 1.823 & 0.069 & -0.302 & 1.316 & 0.189 \\
\hline Spending cycle & 3.473 & 2.736 & 0.006 & 0.468 & 2.769 & 0.006 \\
\hline \multicolumn{7}{|c|}{ (4) High governance countries } \\
\hline Budget balance cycle & 0.995 & 1.864 & 0.063 & -0.201 & 1.113 & 0.266 \\
\hline $\begin{array}{l}\text { Spending cycle } \\
\text { (5) Largest party }\end{array}$ & 2.197 & 1.601 & 0.110 & 0.216 & 1.845 & 0.065 \\
\hline Budget balance cycle & 0.616 & 1.781 & 0.075 & 0.318 & 1.715 & 0.087 \\
\hline \multicolumn{7}{|l|}{ (6) Coalition } \\
\hline Budget balance cycle & 2.053 & 1.832 & 0.067 & -0.512 & 1.553 & 0.121 \\
\hline Spending cycle & 4.765 & 2.875 & 0.004 & 0.368 & 2.184 & 0.029 \\
\hline
\end{tabular}

Note: Column (1) shows the results for the impact of a PBC when we delete the observations which are not in the range: $x<Q(25)-3 I Q R$ or $x>Q(75)+3 I Q R$; column (2) shows the results for the impact of a $\mathrm{PBC}$ for countries which have been democratic for the last fifteen out of twenty years; column (3) shows the results for the impact of a PBC in a sample of countries with low levels of governance; column (4) shows the results for the impact of a $\mathrm{PBC}$ for a sample of countries with high levels of governance; column (5) shows the results for the impact of a PBC on the votes for the largest party in cabinet; and column (6) shows the results for the impact of a PBC using the change of votes of the total coalition as dependent variable

selection of countries in our sample. ${ }^{21}$ As follows from the first part of Table 3, the results are similar to those reported earlier.

Brender and Drazen (2005) argue that voters punish incumbents for deficits and wasteful spending. However, to punish the government voters need to have the information necessary to draw such inferences, as well as the ability to process that information correctly. This requires some experience with the electoral process. In the absence of this experience, it is more likely that fiscal manipulation will be rewarded rather than punished. To control for the learning effect suggested by Brender and Drazen (2005), we re-estimate our models including country-years only if the country concerned has been democratic for at least 15 of the last 20 years. ${ }^{22}$ We still find a mixed sample of countries in which elections have an effect on spending and the budget balance (results are available upon request). The results for the voting model (shown in the second part of Table 3) confirm most of our previous findings. We find a significant direct popularity effect through government spending and an

\footnotetext{
${ }^{21}$ Outliers are defined as: $x<Q(25)-3 I Q R$ or $x>Q(75)+3 I Q R$, where $Q$ is the quantile and $I Q R$ the interquantile range given by 75 th percentile-25th percentile.

${ }^{22}$ See also Akhmedov and Zhuravskaya (2004).
} 
indirect growth effect through government spending. However, the coefficient of the $P B C 2$ budget deficit indicator is no longer significant.

As an additional test, we include in the regressions of Table 1 a variable measuring the number of years since 1945 that a country has been democratic and make the PBC effect conditional on this variable by including an interaction term between it and the election variable. Following Brambor et al. (2006), we calculate the total marginal effect of the interaction term evaluated at the mean of the number of democratic years since 1945 in a country. ${ }^{23}$ The results for the PBC are similar to our earlier results. Also the findings for the second stage regression for votes received by political parties do not change much (all results are available upon request). ${ }^{24}$

Next, earlier studies of the existence of political budget cycles point out that electoral budgetary policies are stronger when politicians are less credible and fiscal policy is less transparent (Alt and Lassen 2006; Keefer and Vlaicu 2008). To examine whether this notion affects our results, we split our sample into two equal-sized groups based on the level of governance. We measure the level of governance by the first principal component of various indicators of corruption, democratic accountability, bureaucracy and rule of law in a particular country-year taken from the International Country Risk Guide. The results in Table 3 show that in both samples the expansionary election effect is significant, although, the impact is larger in the 'low governance' sample.

Finally, our dependent variable is measured at the party level. However, it may be argued that coalition members are considered to be jointly responsible for fiscal policy. Therefore, we use two alternative dependent variables in the second step of our estimation. First, we use the change in votes for the largest coalition party. Second, we use the change in votes for the total coalition. The results in the bottom rows of Table 3 show a similar pattern as in our main model of Table 2 .

\section{Conclusions}

In this paper, we combine two strands of the political economy literature. The first strand focuses on the existence of political budget cycles, while the second strand is concerned with the political and economic determinants of election outcomes.

We find that in most countries fiscal policy is hardly used for electoral purposes. Using a multilevel voting model for coalition parties in government with a large number of control variables, we find that parties in government can influence the election outcome significantly by manipulating government spending. Government spending also has an indirect positive effect on the support received by the parties in government by promoting faster economic growth in the election year. Although we find a statistically significant effect of electioninduced government spending on election outcomes, its economic significance is relatively small. This could explain why fiscal policy is used for election purposes in only a few countries.

\footnotetext{
${ }^{23}$ In contrast, Greene (2010) argues that the significance of the interaction term should be examined using the t-statistic. An insignificant t-statistic indicates a mis-specified econometric model. However, in our case, the interaction term has a p-value of 0.04 , which is significant at a $5 \%$ significance level.

${ }^{24} \mathrm{We}$ also consider an interaction between the election variable and the number of coalition parties. However, the results remain in line with those reported.
} 
Acknowledgements We like to thank participants in seminars at the University of Groningen, the Free University of Berlin, the 2009 conferences of the European Public Choice Society in Athens, the European Economic Association (EEA) in Barcelona, and the International Institute of Public Finance (IIPF) in Cape Town for their comments on previous versions of the paper. We also like to thank an anonymous referee, Helge Berger, Richard Jong-A-Pin and James Vreeland for their very helpful comments.

Open Access This article is distributed under the terms of the Creative Commons Attribution License which permits any use, distribution, and reproduction in any medium, provided the original author(s) and the source are credited.

\section{Appendix 1: Sample of countries and years}

\begin{tabular}{|c|c|c|c|c|c|c|c|c|c|c|}
\hline \multirow{2}{*}{$\begin{array}{l}\text { Country } \\
\text { Albania }\end{array}$} & \multirow{2}{*}{$\begin{array}{l}\begin{array}{l}\text { Included } \\
\text { since }\end{array} \\
1991\end{array}$} & \multicolumn{2}{|c|}{ Balance } & Spending & \multirow{2}{*}{$\begin{array}{l}\text { Country } \\
\text { Japan }\end{array}$} & \multirow{2}{*}{$\begin{array}{l}\begin{array}{l}\text { Included } \\
\text { since }\end{array} \\
1975\end{array}$} & \multicolumn{2}{|c|}{ Balance } & \multicolumn{2}{|c|}{ Spending } \\
\hline & & -2.44 & & 1.37 & & & -1.75 & $\circ$ & 2.45 & $\circ$ \\
\hline Argentina & 1983 & -1.70 & & 1.61 & Korea (South) & 1975 & -0.15 & & 0.16 & \\
\hline Australia & 1976 & -0.97 & & 0.29 & Lithuania $^{*}$ & 1992 & -1.11 & & 1.70 & \\
\hline Austria & 1975 & -0.97 & & 1.06 & Luxembourg & 1976 & -0.84 & & 0.62 & \\
\hline Bangladesh & 1977 & -0.81 & & 1.04 & Malaysia & 1978 & -1.37 & $\circ$ & 2.11 & \\
\hline Belgium & 1977 & -0.38 & & 0.29 & Mali & 1979 & -0.20 & & 0.34 & $\circ$ \\
\hline Bolivia & 1985 & -1.46 & & $0.97 \circ$ & Mauritius & 1981 & -0.65 & $\circ$ & 0.60 & \\
\hline Brazil & 1982 & -0.37 & $\circ$ & $0.37 \circ$ & Mexico & 1976 & -0.47 & & 0.36 & o \\
\hline Bulgaria & 1990 & -0.40 & & $1.32 \circ$ & Nepal $^{*}$ & 1981 & -2.40 & & 1.84 & \\
\hline Canada & 1986 & -0.28 & & 0.23 & Netherlands & 1977 & -2.37 & & 2.20 & \\
\hline Chile & 1975 & -1.19 & & 0.39 & New Zealand & 1977 & -0.76 & $\circ$ & 0.86 & $\circ$ \\
\hline Colombia & 1975 & -1.13 & $\circ$ & $1.40 \circ$ & Nicaragua & 1984 & -1.79 & $\circ$ & 1.50 & \\
\hline Costa Rica & 1975 & 0.06 & & $0.40 \quad \circ$ & Norway & 1977 & -0.20 & & 0.19 & $\circ$ \\
\hline Cyprus & 1975 & -0.27 & & $0.62 \circ$ & Panama & 1989 & -2.30 & & 1.53 & \\
\hline Czech Republic & 1993 & -0.57 & $\circ$ & $0.44 \quad \circ$ & Paraguay & 1978 & -1.26 & & 1.01 & \\
\hline Denmark & 1977 & -0.15 & $\circ$ & 0.30 & Peru & 1980 & -1.16 & & 1.39 & $\circ$ \\
\hline Dominican Rep & 1978 & -0.09 & & 1.63 & Philippines & 1960 & -1.12 & $\circ$ & 0.89 & \\
\hline Ecuador & 1979 & -1.69 & $\circ$ & $1.53 \circ$ & Poland* & 1991 & -0.54 & & 0.95 & \\
\hline El Salvador & 1977 & -1.36 & & 1.08 & Portugal & 1976 & -0.42 & & 0.56 & $\circ$ \\
\hline Estonia $^{*}$ & 1991 & 0.13 & & 1.27 & Romania & 1990 & -1.24 & $\circ$ & 2.00 & $\circ$ \\
\hline Fiji & 1975 & -0.59 & & 0.89 & Slovakia & 1994 & -0.52 & & 0.18 & \\
\hline Finland & 1975 & -0.58 & & 0.61 & South Africa & 1994 & -1.08 & & 1.73 & \\
\hline France & 1977 & -0.75 & $\circ$ & 0.95 & Spain & 1978 & -0.82 & $\circ$ & 0.80 & $\circ$ \\
\hline Germany & 1976 & -0.60 & $\circ$ & 0.71 & Sri Lanka & 1978 & -1.63 & $\circ$ & 0.96 & \\
\hline Greece & 1975 & -0.69 & $\circ$ & 0.62 & Sweden & 1978 & -0.42 & & 0.52 & \\
\hline Guatemala & 1975 & 0.10 & & $0.34 \quad \circ$ & Switzerland & 1975 & -0.54 & $\circ$ & 0.34 & \\
\hline Honduras & 1982 & -0.49 & $\circ$ & $0.49 \circ$ & Trinidad $^{*}$ & 1976 & -0.29 & & 0.38 & \\
\hline Hungary & 1990 & -1.69 & & 1.72 & Turkey & 1976 & -2.56 & $\circ$ & 1.79 & $\circ$ \\
\hline Iceland* & 1975 & -1.08 & & 0.54 & United Kingdom & 1975 & -0.52 & & 0.69 & \\
\hline India & 1977 & -0.55 & & $1.65 \circ$ & United States & 1976 & -0.92 & & 1.05 & \\
\hline Ireland & 1977 & -0.55 & & 0.35 & Uruguay & 1985 & -0.81 & $\circ$ & 1.23 & ० \\
\hline
\end{tabular}




\begin{tabular}{lllllllll}
\hline Country & $\begin{array}{l}\text { Included } \\
\text { since }\end{array}$ & Balance & Spending & Country & $\begin{array}{l}\text { Included } \\
\text { since }\end{array}$ & Balance & Spending \\
\hline Israel & 1977 & -0.79 & 1.11 & $\circ$ & Zambia & 1978 & -1.95 & $\circ$ \\
Italy & 1975 & -0.13 & $\circ$ & 0.23 & $\circ$ & & & 1.04 \\
\hline
\end{tabular}

Note: The figures in the columns show the estimated effect of elections on the fiscal variables. The figures are based on the cross-partial derivative of the PBC coefficient from the semi-pooled model; $\circ$ indicates a significant political budget cycle effect (at 10 percent significance level) in the semi-pooled model

\section{Appendix 2: Data sources}

\begin{tabular}{|c|c|c|}
\hline Variable & Definition & Source \\
\hline Election & Election variable (see main text for details) & $\begin{array}{l}\text { Own calculations based on } \\
\text { Political Handbook of the } \\
\text { World (various issues) }\end{array}$ \\
\hline $\begin{array}{l}\text { Per capita real } \\
\text { income }\end{array}$ & $\begin{array}{l}\text { GDP per capita in } 1970 \text { in constant US dollars of } \\
2000\end{array}$ & World Bank (2006) \\
\hline Economic growth & Growth rate of real GDP per capita & Heston et al. (2006) \\
\hline Globalization & KOF Globalization index & Dreher (2008) \\
\hline Dependency ratio & $\begin{array}{l}\text { The ratio of the population older then } 65 \text { to the } \\
\text { population between } 15 \text { and } 64\end{array}$ & World Bank (2006) \\
\hline Inflation rate & Change in Consumer Price Index & IMF (2006) \\
\hline $\begin{array}{l}\text { Unemployment } \\
\text { rate }\end{array}$ & $\begin{array}{l}\text { Total rate of unemployment of people of } \\
\text { working age }\end{array}$ & $\begin{array}{l}\text { IMF (2006), World Bank } \\
\text { (2006), UN (2006), ILO } \\
\text { (2006), OECD (2006) }\end{array}$ \\
\hline Partisan variable & $\begin{array}{l}\text { Government ideology measure ranging from }-1 \\
\text { (full left wing) to }+1 \text { (full right wing) }\end{array}$ & Update of Beck et al. (2001) \\
\hline $\begin{array}{l}\text { Majoritarian } \\
\text { system }\end{array}$ & $\begin{array}{l}\text { Dummy variable that is one if the election is in a } \\
\text { majority electoral system }\end{array}$ & $\begin{array}{l}\text { Update of Beck et al. (2001), } \\
\text { Election Resources (2007) }\end{array}$ \\
\hline $\begin{array}{l}\text { Parliamentary } \\
\text { system }\end{array}$ & $\begin{array}{l}\text { Dummy variable that is one if the election is in a } \\
\text { parliamentary system }\end{array}$ & $\begin{array}{l}\text { Update of Beck et al. (2001), } \\
\text { Election Resources (2007) }\end{array}$ \\
\hline $\begin{array}{l}\text { Number of } \\
\text { coalition parties }\end{array}$ & Number of coalition parties & $\begin{array}{l}\text { Update of Beck et al. (2001), } \\
\text { Election Resources (2007) }\end{array}$ \\
\hline Monetary union & $\begin{array}{l}\text { Dummy variable taken the value } 1 \text { if a country } \\
\text { year is a member of a monetary union, otherwise } \\
0\end{array}$ & IMF (2006) \\
\hline Change in votes & $\begin{array}{l}\text { Change in the share of votes of government } \\
\text { party } q\end{array}$ & Election Resources (2007) \\
\hline $\begin{array}{l}\text { Average welfare } \\
\text { spending }\end{array}$ & $\begin{array}{l}\text { Sum of government spending on health, } \\
\text { education and social security as a share of GDP }\end{array}$ & $\begin{array}{l}\text { IMF (2006), World Bank } \\
\text { (2006), UN (2006), ILO } \\
\text { (2006), OECD (2006) }\end{array}$ \\
\hline $\begin{array}{l}\text { Change income } \\
\text { distribution }\end{array}$ & $\begin{array}{l}\text { Change in household income inequality within } \\
\text { the government term }\end{array}$ & $\begin{array}{l}\text { University of Texas inequality } \\
\text { project (2006), World Bank } \\
\text { (2006) }\end{array}$ \\
\hline Budget balance & $\begin{array}{l}\text { Government budget balance within the } \\
\text { government term (see main text for details) }\end{array}$ & $\begin{array}{l}\text { IMF (2006), World Bank } \\
(2006), \text { UN (2006), ILO } \\
\text { (2006), OECD (2006) }\end{array}$ \\
\hline Political protest & $\begin{array}{l}\text { First principle component of anti-governmental } \\
\text { demonstrations, strikes, government crises and } \\
\text { cabinet changes. }\end{array}$ & $\begin{array}{l}\text { Own estimations based on } \\
\text { Databanks International } \\
(2005)\end{array}$ \\
\hline
\end{tabular}




\begin{tabular}{|c|c|c|}
\hline Variable & Definition & Source \\
\hline Polarization & $\begin{array}{l}\text { Difference between the ideology of the } \\
\text { incumbent government and the ideology of the } \\
\text { two largest opposition parties }\end{array}$ & Update of Beck et al. (2001) \\
\hline $\begin{array}{l}\text { Majority vs. } \\
\text { proportional }\end{array}$ & $\begin{array}{l}\text { Dummy variable that is one if the election is in a } \\
\text { majority electoral system }\end{array}$ & $\begin{array}{l}\text { Update of Beck et al. (2001), } \\
\text { Election Resources (2007) }\end{array}$ \\
\hline $\begin{array}{l}\text { Parliamentary vs. } \\
\text { presidential }\end{array}$ & $\begin{array}{l}\text { Dummy variable that is one if the election is in a } \\
\text { parliamentary system }\end{array}$ & $\begin{array}{l}\text { Update of Beck et al. (2001), } \\
\text { Election Resources (2007) }\end{array}$ \\
\hline $\begin{array}{l}\text { Number of } \\
\text { parties }\end{array}$ & Number of competing parties in an election & Election Resources (2007) \\
\hline Voter turnout & $\begin{array}{l}\text { Number of voters divided by the population in } \\
\text { the voting age }\end{array}$ & Election Resource (2007) \\
\hline $\begin{array}{l}\text { Term limit chief } \\
\text { executive }\end{array}$ & $\begin{array}{l}\text { Dummy variable that is one if the chief } \\
\text { executive is in his final legal term }\end{array}$ & Update of Beck et al. (2001) \\
\hline $\begin{array}{l}\text { Fractionalization } \\
\text { index }\end{array}$ & $\begin{array}{l}\text { Herfindahl index of the number of seats of } \\
\text { coalition parties }\end{array}$ & $\begin{array}{l}\text { Update of Beck et al. (2001), } \\
\text { Election Resources (2007) }\end{array}$ \\
\hline $\begin{array}{l}\text { Minority } \\
\text { government }\end{array}$ & $\begin{array}{l}\text { Dummy variable that is one if the share of seats } \\
\text { of the government coalition in parliament is less } \\
\text { then } 50 \%\end{array}$ & $\begin{array}{l}\text { Update of Beck et al. (2001), } \\
\text { Election Resources (2007) }\end{array}$ \\
\hline $\begin{array}{l}\text { Number of } \\
\text { coalition parties }\end{array}$ & Number of government parties & $\begin{array}{l}\text { Update of Beck et al. (2001), } \\
\text { Election Resources (2007) }\end{array}$ \\
\hline $\begin{array}{l}\text { Largest coalition } \\
\text { party }\end{array}$ & $\begin{array}{l}\text { Dummy variable if the party is the largest } \\
\text { coalition party }\end{array}$ & Election Resources (2007) \\
\hline $\begin{array}{l}\text { Number of years } \\
\text { in coalition }\end{array}$ & $\begin{array}{l}\text { Total number of years in the coalition without a } \\
\text { switch }\end{array}$ & $\begin{array}{l}\text { Update of Beck et al. (2001) } \\
\text { and own calculations by } \\
\text { extending Beck et al. (2001) }\end{array}$ \\
\hline $\begin{array}{l}\text { Nationalistic } \\
\text { party }\end{array}$ & Dummy variable if the party is nationalistic & $\begin{array}{l}\text { Update of Beck et al. (2001) } \\
\text { and own calculations by } \\
\text { extending Beck et al. (2001) }\end{array}$ \\
\hline $\begin{array}{l}\text { Special interest } \\
\text { party }\end{array}$ & $\begin{array}{l}\text { Dummy variable if the party is based on special } \\
\text { interest issues }\end{array}$ & $\begin{array}{l}\text { Update of Beck et al. (2001) } \\
\text { and own calculations by } \\
\text { extending Beck et al. (2001) }\end{array}$ \\
\hline $\begin{array}{l}\text { Political budget } \\
\text { cycle }\end{array}$ & The PBC indicator (see main text for details) & Own calculations \\
\hline $\begin{array}{l}\text { Election year } \\
\text { growth rate }\end{array}$ & $\begin{array}{l}\text { Weighted growth rate of real GDP per capita } \\
\text { (see main text for details) }\end{array}$ & Heston et al. (2006) \\
\hline Investment & Gross fixed investment as a share of GDP & World Bank (2006) \\
\hline $\begin{array}{l}\text { Population } \\
\text { growth }\end{array}$ & Growth rate of the population & World Bank (2006) \\
\hline Human capital & Secondary education attainment & $\begin{array}{l}\text { EDUSTAT (2006), Barro and } \\
\text { Lee (2001), own calculation } \\
\text { by extending the five year } \\
\text { periods to time series }\end{array}$ \\
\hline
\end{tabular}




\section{Appendix 3: Correlation matrix of control variables}

$$
\begin{aligned}
& \text { 三| }
\end{aligned}
$$

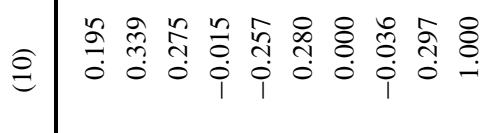

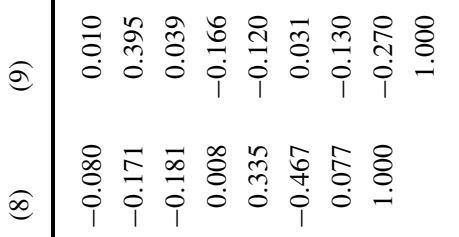

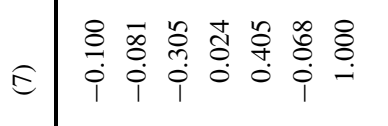

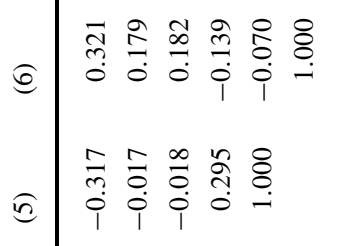

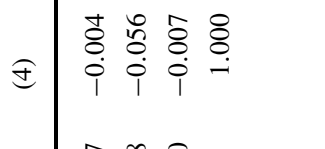

$$
\begin{aligned}
& \text { ๙ิ) } \\
& \text { ฮ| }
\end{aligned}
$$

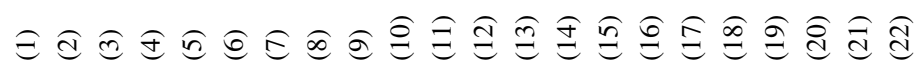

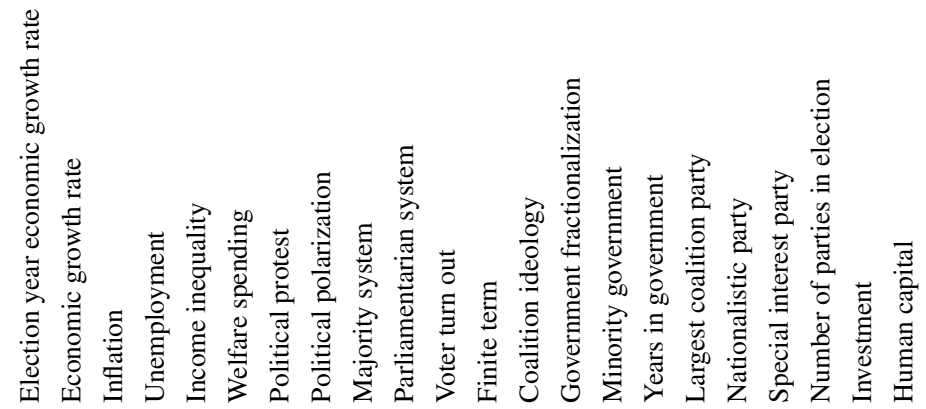




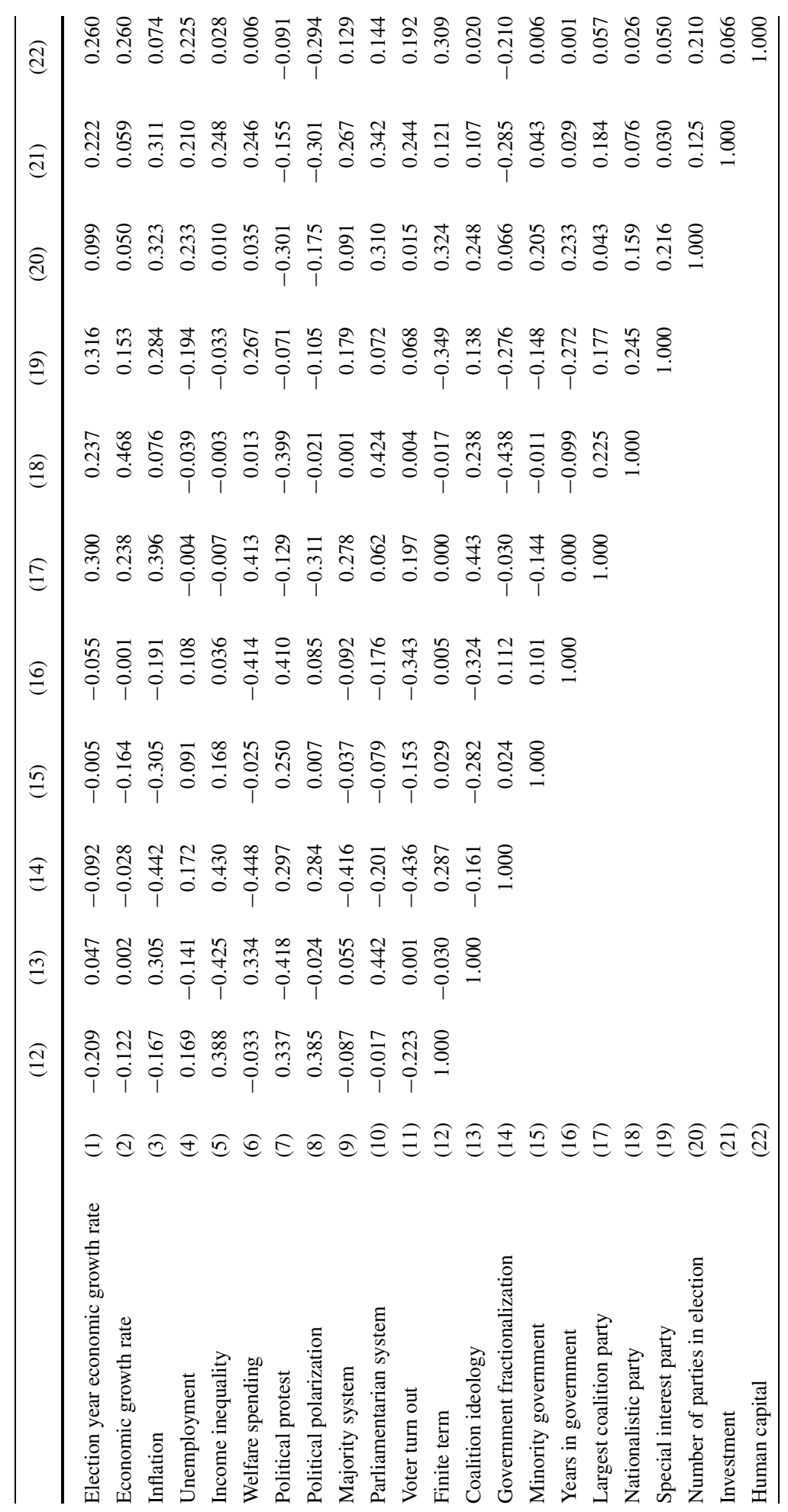




\section{References}

Aidt, T. S., Veiga, F. J., \& Goncalves Veiga, L. (2011). Election results and opportunistic policies: a new test of the rational political business cycle model. Public Choice, 148, 21-44.

Akhemedov, A., \& Zhuravskaya, E. (2004). Opportunistic political cycles: test in a young democracy setting. Quarterly Journal of Economics, 119, 1301-1338.

Alt, J., \& Lassen, D. (2006). Transparency, political polarization and political budget cycles in OECD countries. American Journal of Political Science, 50, 530-550.

Baltagi, B. H. (1995). Econometric analysis of panel data. New York: Wiley.

Banks, A. S., Muller, T. C., \& Overstreet, W. R. (Eds.) (various issues). Political handbook of the world. Washington: CQ Press.

Barro, R. J., \& Lee, J.-W. (2001). International data on educational attainment: updates and implications. Oxford Economic Papers, 53, 541-563.

Bayar, A., \& Smeets, B. (2009). Economic and political determinants of budget deficits in the European Union: a dynamic random coefficient approach. CESifo Working Paper 2546.

Beck, T., Clarke, G., Groff, A., Keefer, P., \& Walsh, P. (2001). New tools in comparative political economy: the database of political institutions. World Bank Economic Review, 15, 165-176.

Block, S. A. (2002). Political business cycles, democratization, and economic reform: the case of Africa. Journal of Development Economics, 67, 205-228.

Brambor, T., Clark, W., \& Golder, M. (2006). Understanding interaction models: improving empirical analysis. Political Analysis, 14, 63-82.

Brender, A. (2003). The effect of fiscal performance on local government election results in Israel: 19891998. Journal of Public Economics, 87, 2187-2205.

Brender, A., \& Drazen, A. (2005). Political budget cycles in new versus established democracies. Journal of Monetary Economics, 52, 1271-1295.

Brender, A., \& Drazen, A. (2008). How do budget deficits and economic growth affect reelection prospects? Evidence from a large cross-section of countries. American Economic Review, 98, 2203-2220.

Databanks International (2005). Cross-national time-series data archive. Binghamton: Databanks International.

Drazen, A., \& Eslava, M. (2006). Pork barrel cycles. NBER Working Paper 12190.

Drazen, A., \& Eslava, M. (2010). Electoral manipulation via voter-friendly spending: theory and evidence. Journal of Development Economics, 92, 39-52.

Dreher, A. (2004). The influence of IMF programs on the re-election of debtor governments. Economics and Politics, 16, 53-75.

Dreher, A. (2006). Does globalization affect growth? Evidence from a new index of globalization. Applied Economics, 38, 1091-1110.

Dreher, A., Sturm, J.-E., \& Ursprung, H. W. (2008). The impact of globalization on the composition of government expenditures: evidence from panel data. Public Choice, 134, 263-292.

EDUSTAT (2006). Edustat. http://www.edustat.org.

Election Resources (2007). http://electionresources.org.

Efthyvoulou, G. (2011). Political budget cycles in the European Union and the impact of political pressures. Public Choice doi:10.1007/s11127-011-9795-x. Forthcoming.

Franzese, R. (2000). Electoral and partisan manipulation of public debt in developed democracies, 19561990. In R. Strauch \& J. Von Hagen (Eds.), Institutions, politics and fiscal policy (pp. 61-83). Dordrecht: Kluwer Academic.

Greene, W. (2010). Testing hypotheses about interaction terms in nonlinear models. Economic Letters, 107, 291-296.

Grier, K. (2008). US presidential elections and real GDP growth, 1961-2004. Public Choice, 135, 337-352.

Hallerberg, M., \& Clark, W. R. (2000). Mobile capital, domestic institutions, and electorally induced monetary and fiscal policy. American Political Science Review, 94, 323-346.

Hanusch, M. (2012). Coalition incentives for political budget cycles. Public Choice, 151, 121-136.

Hendry, D. F. (1993). Econometrics: alchemy or science? Essays in econometric methodology. Oxford: Blackwell.

Heston, A., Summers, R., \& Aten, B. (2006). Penn World Table Version 6.2. Center for international comparisons of production, income and prices. University of Pennsylvania.

Hibbs, D. A. (1987). The American political economy: macroeconomics and electoral politics in the United States. Cambridge: Harvard University Press.

Hobolt, S., \& Klemmensen, R. (2006). Welfare to vote: the effect of government spending on turnout. Midwest Political Science Association Annual Meeting 2006.

Hsiao, C., Pesaran, M., \& Tahmiscioglu, A. (1999). Bayes estimation of short-run coefficients in dynamic panel data models. In C. Hsiao, L. Lee, K. Lahiri, \& M. Pesaran (Eds.), Analysis of panels and limited dependent variables models (pp. 268-296). Cambridge: Cambridge University Press. 
ILO (2006). International Labor Statistics. http://www.ilo.org.

IMF (2006). International financial statistics. Washington: IMF.

Jaggers, K., Marshall, M. G., \& Gurr, T. (2006). Polity IV: political regime characteristics and transitions, 1800-2006. Center for Systemic Peace at George Mason University.

Katsimi, M., \& Sarantides, V. (2012). Do elections affect the composition of fiscal policy in developed, established democracies? Public Choice, 151, 352-362.

Keefer, P., \& Vlaicu, R. (2008). Democracy, credibility and clientelism. Journal of Law, Economics and Organization, 24, 371-406.

Kramer, G. (1971). Short-term fluctuations in U.S. voting behavior, 1896-1964. American Political Science Review, 65, 131-143.

Lewis-Beck, M. S. (1988). Economics and elections: the major western democracies. Ann Arbor: University of Michigan Press.

Lewis-Beck, M. S., \& Stegmaier, M. (2000). Economic determinants of electoral outcomes. Annual Review of Political Science, 3, 183-219.

Mankiw, N. G., Romer, D., \& Weil, D. N. (1992). A contribution to the empirics of economic growth. Quarterly Journal of Economics, 107, 407-437.

Mink, M., \& De Haan, J. (2006). Are there political budget cycles in the euro area? European Union Politics, 7, 191-211.

Nannestad, P., \& Paldam, M. (1994). The VP-function: a survey of the literature on vote and popularity functions after 25 years. Public Choice, 79, 213-245.

Nordhaus, W. D. (1975). The political business cycle. Review of Economic Studies, 42, 169-190.

OECD (2006). OECD statistics. http://www.oecd.org.

Persson, T., \& Tabellini, G. (2002). Do electoral cycles differ across political systems? Mimeo. IIES, Stockholm University.

Pesaran, H., Smith, R. P., \& Im, K. S. (1996). Dynamic linear models for heterogenous panels. In L. Mátyás \& P. Sevestre (Eds.), The econometrics of panel data: a handbook of the theory with applications (pp. 145-195). Dordrecht: Kluwer Academic.

Pesaran, M., Shin, Y., \& Smith, R. (1999). Pooled mean group estimation of dynamic heterogeneous panels. Journal of the American Statistical Association, 94(446), 621-634.

Potrafke, N. (2012). Political cycles and economic performance in OECD countries: empirical evidence from 1951-2006. Public Choice, 150, 155-179.

Rogoff, K., \& Sibert, A. (1988). Elections and macroeconomic policy cycles. Review of Economic Studies, $55,1-16$.

Roubini, N., \& Sachs, J. D. (1989). Political and economic determinants of budget deficits in the industrial democracies. European Economic Review, 33, 903-933.

Schuknecht, L. (1996). Political business cycles and fiscal policies in developing countries. Kyklos, 49, 155170 .

Schuknecht, L. (2000). Fiscal policy cycles and public expenditure in developing countries. Public Choice, 102, 115-130.

Shi, M., \& Svensson, J. (2006). Political budget cycles: do they differ across countries and why? Journal of Public Economics, 90, 1367-1389.

Tufte, E. R. (1978). Political control of the economy. Princeton: Princeton University Press.

Tujula, M., \& Wolswijk, G. (2007). Budget balances in OECD countries: what makes them change? Empirica, 34, 1-14.

United Nations (2006). United Nations statistics. New York: United Nations.

University of Texas (2006). University of Texas Inequality project. http://utip.gov.utexas.edu.

Vergne, C. (2009). Democracy, elections and allocation of public expenditures in developing countries. European Journal of Political Economy, 25, 63-77.

World Bank (2006). World development indicators. CD Rom. 